\title{
Effects of lauric and myristic acids on ruminal fermentation, production, and milk fatty acid composition in lactating dairy cows
}

\author{
A. N. Hristov, ${ }^{\star 1}$ C. Lee, ${ }^{\star}$ T. Cassidy, ${ }^{*}$ M. Long, ${ }^{\star}$ K. Heyler, ${ }^{*}$ B. Corl,, and R. Forster‡ \\ *Department of Dairy and Animal Science, The Pennsylvania State University, University Park 16802 \\ †Department of Dairy Science, Virginia Polytechnic Institute and State University, Blacksburg 24061 \\ łLethbridge Research Centre, Agriculture and Agri-Food Canada, Lethbridge, Canada AB T1J 4B1
}

\section{ABSTRACT}

The objectives of this experiment were to investigate the effects of lauric (LA) and myristic (MA) acids on ruminal fermentation, production, and milk fatty acid (FA) profile in lactating dairy cows and to identify the FA responsible for the methanogen-suppressing effect of coconut oil. The experiment was conducted as a replicated $3 \times 3$ Latin square. Six ruminally cannulated cows $(95 \pm 26.4 \mathrm{DIM})$ were subjected to the following treatments: $240 \mathrm{~g} / \mathrm{cow}$ per day each of stearic acid (SA, control), LA, or MA. Experimental periods were 28 $\mathrm{d}$ and cows were refaunated between periods. Lauric acid reduced protozoal counts in the rumen by $96 \%$, as well as acetate, total VFA, and microbial N outflow from the rumen, compared with SA and MA. Ruminal methane production was not affected by treatment. Dry matter intake was reduced $35 \%$ by LA compared with SA and MA, which resulted in decreased milk yield. Milk fat content also was depressed by LA compared with SA and MA. Treatment had no effect on milk protein content. All treatments increased milk concentration of the respective treatment FA. Concentration of C12:0 was more than doubled by LA, and C14:0 was increased (45\%) by MA compared with SA. Concentration of milk FA $<$ C16 was $20 \%$ lower for LA than MA. Concentrations of trans 18:1 FA (except trans 12) and CLA isomers were increased by LA compared with SA and MA. Overall, the concentrations of saturated FA in milk fat were reduced, and that of $>\mathrm{C} 16 \mathrm{FA}$ and MUFA were increased, by LA compared with the other treatments. In this study, LA had profound effects on ruminal fermentation, mediated through inhibited microbial populations, and decreased DMI, milk yield, and milk fat content. Despite the significant decrease in protozoal counts, however, LA had no effect on ruminal methane production. Thus, the antimethanogenic effect of coconut oil, observed in related studies, is likely due to total FA application level, the additive effect of LA

Received June 5, 2010.

Accepted September 18, 2010.

${ }^{1}$ Corresponding author: anh13@psu.edu and MA, or a combination of both. Both LA and MA modified milk FA profile significantly.

Key words: dairy cow, lauric acid, myristic acid, milk fatty acid

\section{INTRODUCTION}

On a global scale, greenhouse gas (GHG) emissions from livestock amount to approximately $18 \%$ of all anthropogenic GHG emissions according to a report by the Food and Agriculture Organization of the United Nations (FAOUN, 2006). In some industrialized countries, however, enteric methane production by ruminants contributes only a small proportion of total GHG emissions. In the United States, for example, livestock contribution to GHG emissions is a mere $2.2 \%$, based on US Environmental Protection Agency data (US EPA, 2007). These discrepancies can be easily explained by differences in the relative contributions of the energy, transportation, and livestock sectors in developed vs. developing countries (Hristov, 2008) and also by methodology inconsistencies (Pitesky et al., 2009). Irrespective of these disagreements, however, animal scientists are increasingly investigating methods for reducing enteric methane emissions from ruminant animals (Boadi et al., 2004; Bodas et al., 2008). Apart from being a pollutant, methane also represents a significant energy loss to the animal (Moe and Tyrrell, 1979).

Fatty acids (FA) have been investigated and may be an attractive tool to control rumen methanogenesis. In general, long-chain unsaturated and medium-chain saturated FA (MCSFA) were effective in inhibiting methanogens or decreasing methane production in vitro or in vivo (Henderson, 1973; Odongo et al., 2007; Johnson et al., 2009), but in some cases, the effects were biologically or statistically insignificant (Dohme et al., 2001; Beauchemin et al., 2009). Medium-chain saturated FA have strong antiprotozoal properties (Hristov et al., 2004a,b, 2009), and it has been suggested that the effects of defaunation and direct inhibition of archaea by MCSFA on methane suppression is additive (Dohme et al., 1999), although this association is not always clear (Karnati et al., 2009). Lauric (C12:0; LA) and myris- 
tic acids (C14:0; MA) compose approximately $63 \%$ of coconut oil, with about $10 \%$ palmitic and 7 to $8 \%$ oleic acids (CRC, 1988), and coconut oil has been effective in mitigating enteric methane production in ruminants. In a recent experiment with dairy cows, we found no effect on methane production with LA, but a significant reduction with coconut oil (Hristov et al., 2009). In sheep, 3.5 or $7.0 \%$ dietary inclusion of coconut oil reduced methane production by 27 and $73 \%$, respectively (Machmüller and Kreuzer, 1999). Thus, supplementation of cattle diets with coconut oil may be a practically feasible method of mitigating enteric methane emission from ruminants and the environmental impact of livestock operations. It is important, however, to identify the methane-suppressing properties of the 2 major FA in coconut oil. Machmüller (2006) reported dramatic decreases (up to 50\%) in methane production with both LA and MA at dietary inclusion levels below $3 \%$. Odongo et al. (2007) reported a 36\% reduction in methane production in dairy cows fed a diet supplemented with 5\% MA. Other reports, however, found no effect of MA on ruminal methanogenesis (Dohme et al., 2001; Soliva et al., 2003). Then, there are some indications that the effect of LA and MA on methane production is additive (Soliva et al., 2004; Machmüller, 2006). Thus, it remains uncertain which FA is responsible for the antimethanogenic effect of coconut oil, or if the effect of LA and MA is additive.

Therefore, the objective of this study was to investigate the effect of LA and MA individually, on ruminal fermentation, methanogenesis, and production in lactating dairy cows. Our hypothesis, based on previous observations (Hristov et al., 2004a,b), was that LA is the FA primarily responsible for the methanogenesis inhibition observed with coconut oil (Hristov et al., 2009).

\section{MATERIALS AND METHODS}

Animals involved in this study were cared for according to the guidelines of The Pennsylvania State University Animal Care and Use Committee. The committee reviewed and approved the experiment and all procedures carried out in the study.

\section{Animals and Experimental Design}

Six multiparous Holstein cows $(666 \pm 14.4 \mathrm{~kg}$ of BW; $95 \pm 26$ DIM at the start of the trial) fitted with 10 cm ruminal cannulas (Bar Diamond, Parma, ID) were used. Cows were randomly assigned to experimental treatments in a replicated $3 \times 3$ Latin square design balanced for residual effects. Treatments were as fol- lows: $240 \mathrm{~g} /$ cow per d each of stearic (SA, minimum 98\% stearic acid; control), lauric (minimum 99\% LA), or myristic (minimum 98\% MA) acids. Lauric and myristic acids were from KIC Chemicals, Inc. (New Paltz, NY). Stearic acid was from Brenntag Nederland BV (Dordrecht, the Netherlands). The application level of $240 \mathrm{~g} / \mathrm{cow}$ and application method (intraruminal) were chosen based on previous studies (Hristov et al., 2004b, 2009; Faciola et al., 2005, 2008). Stearic acid was used as a control treatment as it has minimal effects on ruminal fermentation (Hristov et al., 2004a). Treatments were applied as a pulse dose once a day (immediately before morning feeding) throughout the 21-d experimental periods, directly into the rumen via the cannula by mixing with approximately $5 \mathrm{~kg}$ of whole ruminal contents. The basal diet was fed as a TMR (Table 1). As formulated and at $27 \mathrm{~kg} / \mathrm{d}$ of DMI, the diet exceeded the $\mathrm{NE}_{\mathrm{L}}$ requirements of a Holstein cow yielding $45 \mathrm{~kg}$ of milk/d containing $3.40 \%$ milk fat and $3.00 \%$ milk true protein, but was deficient in $\operatorname{RDP}(-66 \mathrm{~g} / \mathrm{d})$ and MP $(-269 \mathrm{~g} / \mathrm{d})$ according to NRC (2001). Cows were offered the daily ration as equal meals at 0800 and $2000 \mathrm{~h}$. Diets were fed ad libitum in amounts resulting in $5 \%$ refusals. Each experimental period comprised a 21-d treatment adaptation and 7 $\mathrm{d}$ for sampling. On the last day of periods 1 and 2 , all cows were transfaunated with approximately $20 \mathrm{~kg} /$ cow of whole ruminal contents from donor cows fed the same basal diet (not supplemented with FA). Following a 7-d refaunation period, the cows were assigned to new treatments. On d 7 of the refaunation period, a whole-ruminal-contents sample was collected before the a.m. feeding from the bottom of the rumen. The contents were squeezed through 2 layers of cheesecloth, and protozoa were counted as described below. Cows were housed in a tiestall barn during the entire trial and were exercised for about $3 \mathrm{~h} / \mathrm{d}$ during regular milking (twice daily). Cows had continuous access to fresh water. One square (3 cows) received and the other (3 cows) did not receive recombinant bST (rbST) during the entire trial.

\section{Sampling and Measurements}

Samples of forage, TMR, and refusals were collected daily, and concentrate feeds were sampled weekly. Feed samples were composited and analyzed for $\mathrm{DM}\left(65^{\circ} \mathrm{C}\right.$ in a forced-air oven, dried to a constant weight) ash/OM (AOAC, 2000), N (Kjeldahl; AOAC, 1980), NDF (Van Soest et al., 1991), and starch (starch assay kit, Megazyme International Ireland Ltd., Wicklow, Ireland; McCleary et al., 1994). A heat-stable $\alpha$-amylase was used in the NDF analysis. Sodium sulfite was not used in the 
analysis and NDF was expressed inclusive of residual ash. Composite TMR samples also were analyzed for acid-insoluble ash (Van Keulen and Young, 1977).

Whole ruminal contents samples were collected at 2, $4,6,8,10,14,18$, and $24 \mathrm{~h}$ following the morning feeding on d 23 of each experimental period. Ruminal samples were collected from 4 locations in the rumen and the reticulum (approximately $250 \mathrm{~g}$ each) and composited; aliquots were filtered through cheesecloth. Subsamples of the cheesecloth filtrates were immediately analyzed for $\mathrm{pH}$ and processed for analyses of ammonia (Chaney and Marbach, 1962), total free AA (ninhydrin procedure; Snell and Snell, 1954), VFA (Yang and Varga, 1989), and polysaccharide-degrading activities (carboxymethylcellulase, amylase, and xylanase; Hristov et al., 1998). Samples for protozoal enumeration were preserved (Hristov et al., 2001) and counted according to standard procedures (Dehority, 1993). Generic distribution of protozoa was determined from the total number of cells of each genera counted in 100 fields using the Sedgewick-Rafter chamber (Hausser Scientific, Horsham, PA).

Methane, nitrous oxide, and carbon dioxide production in the rumen were measured using the sulfur hexafluoride $\left(\mathrm{SF}_{6}\right)$ tracer technique (Johnson et al., 1994). The $\mathrm{SF}_{6}$ permeation tubes were prepared by K. Johnson (Washington State University, Pullman) and placed in the reticulum of the cows on $\mathrm{d} 1$ of the experiment. The tubes remained there for the duration of the entire study. Gas samples for methane analysis were collected directly from the rumen through modified rumen cannula lids as described elsewhere (Hristov et al., 2009) at 2, 3, 4, 5, and $6 \mathrm{~h}$ after the a.m. feeding on d 22 of each experimental period. Gas samples were analyzed for methane, nitrous oxide, and carbon dioxide, as well as $\mathrm{SF}_{6}$ on a photoacoustic gas analyzer (INNOVA model 1412, AirTech Instruments, Ballerup, Denmark). Methane, carbon dioxide, and nitrous oxide production was calculated as the release rate of $\mathrm{SF}_{6}$ times the ratio of the concentration of methane, carbon dioxide, or nitrous oxide to $\mathrm{SF}_{6}$ in the ruminal headspace (Johnson et al., 1994).

Samples of whole ruminal contents (approx. $70 \mathrm{~g}$ ) were stored frozen at $-20^{\circ} \mathrm{C}$ for further DNA analysis. The samples were thawed and then mixed with an equal volume of phosphate buffer. The samples were homogenized $(3 \times 20 \mathrm{~s})$ with a handheld Braun homogenizer (Bronwill Scientific Co., Rochester, NY). The liquid was separated from the remaining solids with a Bodum filter plunger (Bodum USA Inc., New York, NY). Five-milliliter samples of liquid were centrifuged 10 min at $10,000 \times g$. The supernatant was discarded and the remaining bacterial pellet was resuspended in $1.4 \mathrm{~mL}$ of ASL buffer (Qiagen Sciences, La Jolla, CA).
Table 1. Ingredient and chemical composition of the basal diet fed in the trial

\begin{tabular}{|c|c|}
\hline Ingredient $^{1}$ & $\begin{array}{l}\% \text { of } \\
\mathrm{DM}\end{array}$ \\
\hline Corn silage $^{2}$ & 47.6 \\
\hline Grass hay ${ }^{3}$ & 10.2 \\
\hline Corn grain, ground & 6.9 \\
\hline Canola meal, mechanically extracted & 8.9 \\
\hline Soybean seeds, whole, heated & 10.2 \\
\hline Cookie by-product ${ }^{4}$ & 5.9 \\
\hline Cottonseed hulls & 2.2 \\
\hline Sugar blend ${ }^{5}$ & 4.2 \\
\hline Mineral/vitamin premix $^{6}$ & 3.5 \\
\hline Optigen $^{7}$ & 0.4 \\
\hline \multicolumn{2}{|l|}{ Composition, ${ }^{8} \%$ of DM or as indicated } \\
\hline $\mathrm{CP}$ & 14.4 \\
\hline Soluble protein, $\%$ of $\mathrm{CP}$ & 31.7 \\
\hline $\mathrm{RDP},{ }^{9} \%$ of $\mathrm{CP}$ & 65.8 \\
\hline NDF & 34.8 \\
\hline $\mathrm{ADF}$ & 21.6 \\
\hline $\mathrm{NE}_{\mathrm{L}}, \mathrm{Mcal} / \mathrm{kg}$ & 1.67 \\
\hline Starch & 26.4 \\
\hline $\mathrm{NFC}$ & 41.4 \\
\hline $\mathrm{Ca}$ & 0.69 \\
\hline $\mathrm{P}$ & 0.33 \\
\hline
\end{tabular}

${ }^{1}$ In addition to the basal diet, cows received $240 \mathrm{~g} / \mathrm{d}$ of fatty acids, which would add approximately $1.8 \mathrm{Mcal} / \mathrm{d}$ of digestible energy (based on the energy content of vegetable oil; NRC, 2001).

${ }^{2}$ Corn silage was on average $37.1 \%$ DM and (as \% of DM): $34.7 \%$ NDF, $7.7 \% \mathrm{CP}$, and $42.1 \%$ starch.

${ }^{3}$ Grass hay contained (as \% of DM): $75.2 \% \mathrm{NDF}$ and $5.8 \% \mathrm{CP}$.

${ }^{4}$ Cookie by-product (Bakery Feeds, Honey Brook, PA) contained (as \% of DM): $9 \% \mathrm{CP}, 8 \%$ ether extract, and $5 \%$ crude fiber.

${ }^{5}$ Sugar blend (Westway Feed Products, Tomball, TX) contained (as \% of $\mathrm{DM}): 3.9 \% \mathrm{CP}$ and $66 \%$ total sugar.

${ }^{6}$ The premix contained (\%, as-is basis): trace mineral mix, $0.88 ; \mathrm{MgO}$ $(54 \% \mathrm{Mg}), 8.3 ; \mathrm{NaCl}, 6.4$; vitamin ADE premix, 1.73; limestone, 35.8; selenium premix, 1.09; and dry corn distiller grains with solubles, 45.8 . Composition: Ca, $14.1 \%$; P, $0.35 \%$; Mg, $4.58 \%, \mathrm{~K}, 0.41 \%$; S, $0.31 \%$; Mn, 1,071 mg/kg; Cu, $358 \mathrm{mg} / \mathrm{kg}$; Zn, 1,085 mg/kg; Fe, $181 \mathrm{mg} / \mathrm{kg}$; Se, $6.67 \mathrm{mg} / \mathrm{kg}$; Co, $5.4 \mathrm{mg} / \mathrm{kg} ; \mathrm{I}, 13.4 \mathrm{mg} / \mathrm{kg}$; vitamin A, 262,101 IU/ $\mathrm{kg}$; vitamin D, 65,421 IU/kg; and vitamin E, 1,971 IU/kg.

${ }^{7}$ Optigen is a nonprotein nitrogen source $(243.2 \% \mathrm{CP}, \mathrm{DM}$ basis $)$ from Alltech, Inc. (Nicholasville, Kentucky).

${ }^{8}$ As analyzed by Cumberland Valley Analytical Services (Maugansville, MD).

${ }^{9}$ Estimated based on NRC (2001).

The DNA was then extracted using a Qiagen DNA kit (Qiagen Sciences) according to the manufacturer's protocol and eluted in $50 \mu \mathrm{L}$ of Tris- EDTA buffer $(0.1 \mathrm{M}$ Tris, $1 \mathrm{~m} M$ EDTA; $\mathrm{pH} 7.5)$. The DNA concentration was measured using a PicoGreen dsDNA quantitation kit (molecular probes, Invitrogen, Eugene, OR) in a multidetection microplate reader (model SIAFRM, BioTek Instruments Inc., Winooski, VT) with calf thymus DNA (Sigma-Aldrich, St. Louis, MO) as the standard. Concentrations were adjusted to $10 \mathrm{ng} / \mu \mathrm{L}$ and used for further experiments.

To evaluate diversity differences in the archaeal populations, DNA fingerprinting profiles of the archaeal 
communities were generated using denaturing gradient gel electrophoresis (DGGE). The DGGE was performed with an approximately 500-bp fragment of the 16S rRNA gene (v3-v6 region) as described by OheneAdjei et al. (2007). The DNA from individual animals was used as the template. Briefly, PCR was conducted using Arch 344F (ACG GGG YGC AGC AGG CGC GA) and Arch 915R (GTG CTC CCC CGC CAA TTC CT) primers. The forward primer had an added 40bp GC clamp (Muyzer and Smalla, 1998). The final volume $(25 \mathrm{uL})$ of all PCR reactions contained $20 \mathrm{ng}$ of template, $2.5 \mu \mathrm{L}$ of $10 \times$ dilution buffer, $10 \mathrm{pmol}$ of each primer, and $1 \mathrm{U}$ of Taq polymerase (Takara Shuzo, Japan). All PCR amplifications were performed using a 96 well i-Cycler (Bio-Rad Laboratories, Hercules, CA). The amplification conditions involved denaturation at $95^{\circ} \mathrm{C}$ for $1 \mathrm{~min}$, followed by 35 cycles of $95^{\circ} \mathrm{C}$ for $30 \mathrm{~s}$, $54^{\circ} \mathrm{C}$ for $30 \mathrm{~s}$, and $72^{\circ} \mathrm{C}$ for $1 \mathrm{~min}$.

Quantitative PCR was used to evaluate the population size of total archaea as described by Ohene-Adjei et al. (2007). Quantitative PCR was performed on a 96-well ABI 7900HT (Applied Biosystems, Foster City, CA) using SYBR Green Master Mix (Applied Biosystems, Foster City, CA) according to the manufacturer's protocol. The Arch 896-915 F (AGG AAT TGG CGG GGG AGC AC) and the Arch 1406-1389 R (ACG GGC GGT GTG TGC AAG) primer sets were used for the quantitation of total archaea. A reaction mix $(20 \mu \mathrm{L})$ contained $20 \mathrm{ng}$ of genomic DNA and $10 \mathrm{pmol}$ of each primer. The cycling conditions were 40 cycles of $95^{\circ} \mathrm{C}$ for $15 \mathrm{~s}$, and $60^{\circ} \mathrm{C}$ for $60 \mathrm{~s}$.

Fecal samples (400 g/sampling) were collected from the rectum or the ground (when fresh) during the first $2 \mathrm{~d}$ of each sampling period at 0900, 1500, and $2100 \mathrm{~h}$ (d 22), and at 0300, 0600, 1200, 1800, and $0000 \mathrm{~h} \mathrm{(d} 23$ and 24). Samples were dried at $65^{\circ} \mathrm{C}$ in a forced-air oven to constant weight, composited per animal and period, and ground through a 1-mm sieve. Samples were analyzed for ash (OM), N, NDF, starch, and acid-insoluble ash. Apparent total-tract digestibility was estimated using acid-insoluble ash as an intrinsic marker (Foley et al., 2006). At each sampling, an additional fecal sample (approximately $300 \mathrm{~g}$ ) was collected, composited (per cow and treatment), and immediately frozen $\left(-20^{\circ} \mathrm{C}\right)$ for analysis of gaseous emissions from manure.

Total urine collection was performed during the last $4 \mathrm{~d}$ of each experimental period. Urinary catheters (22 French, 75 mL, C. R. Bard Inc., Covington, GA) were positioned in the cows $24 \mathrm{~h}$ before the initiation of the urine collection. Urine samples were acidified during collection to a $\mathrm{pH}<3.0$ by addition of $2 \mathrm{M}$ sulfuric acid. Aliquots were diluted 1:10 with distilled water, stored frozen at $-20^{\circ} \mathrm{C}$, and later analyzed for $\mathrm{N}$, allantoin (Chen, 1989), and uric acid (uric acid kit 1051, Stanbio
Laboratory, San Antonio, TX). Urinary excretion of purine derivatives, allantoin and uric acid, was used to estimate duodenal microbial $\mathrm{N}$ flow. At the beginning of each urine collection period, a nonacidified sample of urine (approximately $2 \mathrm{~L}$ ) was collected from each cow, frozen immediately $\left(-20^{\circ} \mathrm{C}\right)$, and subsequently used for the analysis of gaseous emissions from manure.

Ammonia, methane, and nitrous oxide emitting potential of manure resulting from the respective diet changes were measured in a steady-state gas emission system (Wheeler et al., 2007). Emission measurements in this experiment were conducted at $25^{\circ} \mathrm{C}$ with 2 - $\mathrm{L} /$ min sweep airflow. Feces and urine (see above paragraphs) were thawed and mixed 1.7:1 (252 $\mathrm{g}$ of feces and $148 \mathrm{~g}$ of urine per jar) and incubated for $165 \mathrm{~h}$. The feces:urine ratio was chosen based on experiments from the senior author's laboratory, in which fecal and urinary $\mathrm{N}$ output was measured in lactating dairy cows. Ammonia, methane, and nitrous oxide concentrations in the gas leaving the chambers were measured with an INNOVA gas analyzer. Gas measurements were taken every $30 \mathrm{~min}$. Nitrous oxide concentration in manure gas was negligible in this experiment (around $0.6 \mathrm{mg}$ / $\mathrm{m}^{3}$ ) and nitrous oxide emissions will not be further discussed.

Milk yield data were collected daily and milk samples (a.m. and p.m. milkings) for composition analyses (Dairy One, Ithaca, NY) were collected on 3 separate days during the last $2 \mathrm{wk}$ of each period. Milk samples for fatty acid composition were collected and stored at $-20^{\circ} \mathrm{C}$ until analyzed according to Hristov et al. (2010).

On d 27 of each experimental period, blood samples were collected from the tail vein/artery immediately before and $6 \mathrm{~h}$ after morning feeding. Plasma was obtained by centrifugation at $1,500 \times g$ for $40 \mathrm{~min}$, frozen at $-40^{\circ} \mathrm{C}$, and later analyzed for urea $\mathrm{N}$ (kit 0580, Stanbio Laboratory) and glucose (kit 1075, Stanbio Laboratory) concentrations.

Body weight of the cows was recorded throughout the experiment. Urinary purine derivatives excretion was used to estimate duodenal microbial $\mathrm{N}$ flow (for equations, see Hristov et al., 2009). A ratio of purine $\mathrm{N}$ to total $\mathrm{N}$ in rumen microorganisms of 0.134 was assumed based on the data of Valadares et al. (1999).

\section{Statistical Analysis}

Data were analyzed using PROC MIXED of SAS (SAS Inst., Inc., Cary, NC). Intake, digestibility, ruminal enzymatic activities and protozoal counts, urinary excretion measurements, milk yield and composition, and end-point (165 h) cumulative ammonia and methane emission from manure data were analyzed by 
ANOVA Latin square. Milk composition data collected during each experimental period were averaged per cow, and the average values were used in the statistical analysis and to calculate $\mathrm{FCM}$, milk $\mathrm{NE}_{\mathrm{L}}$, and milk fat and protein yields. Data were analyzed according to the following model:

$$
\mathrm{Y}_{\mathrm{ijkl}}=\mu+\mathrm{G}_{\mathrm{i}}+\mathrm{C}(\mathrm{G})_{\mathrm{ij}}+\mathrm{P}_{\mathrm{k}}+\tau_{\mathrm{l}}+\mathrm{e}_{\mathrm{ijkl}},
$$

where $Y_{i j k l}$ is the dependent variable, $\mu$ is the overall mean, $\mathrm{G}_{\mathrm{i}}$ is the group, $\mathrm{C}(\mathrm{G})_{\mathrm{ij}}$ is the cow within group, $\mathrm{P}_{\mathrm{k}}$ is the kth period, $\tau_{1}$ is the lth treatment, with the error term $e_{i j k l}$ assumed to be normally distributed with mean $=0$ and constant variance. Group and cow within group were random effects, whereas all other factors were fixed.

Ruminal pH, ammonia and VFA concentrations, and methane, carbon dioxide, and nitrous oxide production data were analyzed as Latin square repeated measures assuming an autoregressive(1) covariance structure fitted on the basis of Akaike information and Schwarz Bayesian model-fit criteria according to the following model:

$$
\begin{aligned}
Y_{\mathrm{ijklm}}=\mu+ & \mathrm{G}_{\mathrm{i}}+\mathrm{C}(\mathrm{G})_{\mathrm{ij}}+\mathrm{P}_{\mathrm{k}}+\tau_{\mathrm{l}}+\mathrm{D}_{\mathrm{m}} \\
& +\tau \mathrm{D}_{\mathrm{lm}}+\mathrm{e}_{\mathrm{ijklm}},
\end{aligned}
$$

where $Y_{\mathrm{ijklm}}$ is the dependent variable, $\mu$ is the overall mean, $\mathrm{G}_{\mathrm{i}}$ is the group, $\mathrm{C}(\mathrm{G})_{\mathrm{ij}}$ is the cow within group, $\mathrm{P}_{\mathrm{k}}$ is the kth period, $\tau_{1}$ is the lth treatment, $\mathrm{D}_{\mathrm{m}}$ is the time effect, $\tau \mathrm{D}_{\operatorname{lm}}$ is the treatment $\times$ time interaction, with the error term $e_{i j k l m}$ assumed to be normally distributed with mean $=0$ and constant variance. Group and cow within group were random effects, whereas all else were fixed.

Cumulative ammonia and methane emissions from manure data were fitted (PROC NLIN, SAS) to a single rectangular 2-parameter hyperbola model of the type $f$ $=\mathrm{a} \times \mathrm{x} \div(\mathrm{b}+\mathrm{x})$, in which $\mathrm{f}$ was cumulative ammonia or methane emission $(\mathrm{mg})$, a represented the theoretical maximum of ammonia or methane emissions, $\mathrm{x}$ was incubation time $(\mathrm{h})$, and $\mathrm{b}$ was the regression constant. The average proportion of the variance explained by the models (regression sum of squares $\div$ uncorrected total sum of squares) was $0.98 \pm 0.001$ and $0.96 \pm$ 0.007 for ammonia and methane respectively. Estimated maximum emission and overall emission lines were compared between treatments using the dummy variable regression technique (PROC NLMIXED, SAS; Bates and Watts, 1988).

Statistical differences were declared at $P \leq 0.05$. Differences between treatments at $P \leq 0.10$ were considered as a trend toward significance.

\section{RESULTS}

Rumen $\mathrm{pH}$ was higher $(P=0.049)$ for LA compared with SA and MA (Table 2); no treatment $\times$ time of sampling interaction was observed. Ammonia concentration in ruminal fluid was decreased $(P=0.044)$ by LA compared with MA and tended to be decreased $(P=0.084)$ compared with SA. Rumen ammonia concentration was lower for LA after the p.m. feeding, but similar to the other treatments during the rest of the sampling period (Figure 1). There was no effect of treatment on concentration of total free AA. Lauric acid had a dramatic effect on ruminal fermentation by decreasing $(P=0.007$ and $<0.001)$ concentrations of total VFA and acetate compared with SA and MA. Myristic acid had no effect on VFA. Total protozoal counts were reduced $(96 \% ; P<0.001)$ by LA compared with SA and MA. The same effect was observed for Entodinium spp. Other protozoal species were not detected in the LA-treated cows and were low in the other treatments. Fibrolytic (carboxymethylcellulase and xylanase) activities were not reduced by LA compared with the other treatments, and amylase activity of ruminal contents was increased $(P=0.043)$ by LA compared with SA.

Concentration of nitrous oxide in the rumen gas phase was very low compared with that of methane and carbon dioxide, but was reduced $(P=0.020)$, particularly $2 \mathrm{~h}$ after the a.m. feeding (Figure 2), by LA compared with SA and MA. Production rate of nitrous oxide was about $0.2 \%$ of that of methane and was reduced $(P=$ 0.002 ) by LA compared with SA and MA $2 \mathrm{~h}$ after feeding (treatment $\times$ time interaction, $P=0.065$ ). Lauric acid also reduced $(P=0.039)$ ruminal concentration of carbon dioxide compared with SA and tended to reduce it $(P=0.098)$ compared with MA. Production rate of carbon dioxide was not affected by treatment. Concentration and production rate of methane were also not affected by treatment. It appears methane concentration tended to be lower for LA throughout the sampling period (Figure 3), but the differences did not reach statistical significance because of the large variability in the data.

Quantitative PCR was used to determine the effect of the treatments on the $16 \mathrm{~S}$ rRNA copy number of methanogenic archaea. Statistical analysis of the data indicated that there were no significant differences in the estimated copy numbers of methanogenic archaea between treatments. Additionally, DGGE analysis did not show any variance in the number or size distribution of DNA bands between animals or diets, indicating that the population structure of the methanogenic archaea in the rumen did not change (data not shown). 
Table 2. Effect of medium-chain saturated fatty acids ${ }^{1}$ on rumen fermentation and BUN in dairy cows (least squares means; $\mathrm{n}=160$, rumen $\mathrm{pH}$, ammonia, and VFA data; $\mathrm{n}=90$, rumen methane, nitrous oxide, and carbon dioxide; and $\mathrm{n}=18$, all other variables)

\begin{tabular}{|c|c|c|c|c|c|}
\hline Item & SA & LA & MA & SEM & $P$-value \\
\hline \multicolumn{6}{|l|}{ Rumen } \\
\hline $\mathrm{pH}$ & $6.17^{\mathrm{b}}$ & $6.36^{\mathrm{a}}$ & $6.13^{\mathrm{b}}$ & 0.056 & $0.049^{2}$ \\
\hline Ammonia, $\mathrm{m} M$ & $4.03^{\mathrm{ab}}$ & $3.10^{\mathrm{b}}$ & $4.41^{\mathrm{a}}$ & 0.324 & $0.044^{3}$ \\
\hline Total free AA, mM & 4.86 & 4.72 & 5.26 & 0.395 & 0.57 \\
\hline Total VFA, ${ }^{4} \mathrm{~m} M$ & $114.0^{\mathrm{a}}$ & $104.6^{\mathrm{b}}$ & $114.9^{\mathrm{a}}$ & 2.20 & 0.007 \\
\hline Acetate & $67.9^{\mathrm{a}}$ & $58.5^{\mathrm{b}}$ & $67.4^{\mathrm{a}}$ & 1.22 & $<0.001$ \\
\hline Propionate & 27.9 & 27.1 & 28.7 & 1.40 & 0.64 \\
\hline Isobutyrate & $1.22^{\mathrm{a}}$ & $1.11^{\mathrm{b}}$ & $1.21^{\mathrm{a}}$ & 0.023 & 0.001 \\
\hline Butyrate & 12.6 & 12.5 & 13.5 & 0.44 & 0.29 \\
\hline Isovalerate & $1.87^{\mathrm{b}}$ & $2.22^{\mathrm{a}}$ & $1.92^{\mathrm{b}}$ & 0.081 & 0.022 \\
\hline Valerate & $2.43^{\mathrm{b}}$ & $3.16^{\mathrm{a}}$ & $2.52^{\mathrm{b}}$ & 0.173 & $0.002^{5}$ \\
\hline Acetate:propionate & 2.53 & 2.23 & 2.47 & 0.170 & $0.06^{6}$ \\
\hline Total protozoa, $\times 10^{4} / \mathrm{mL}$ & $88.0^{\mathrm{a}}$ & $3.8^{\mathrm{b}}$ & $102.7^{\mathrm{a}}$ & 18.72 & $<0.001^{7}$ \\
\hline Entodinium spp. & $83.9^{\mathrm{a}}$ & $3.8^{\mathrm{b}}$ & $97.0^{\mathrm{a}}$ & 18.16 & $<0.001$ \\
\hline Isotricha spp. & 0.29 & $\mathrm{ND}^{8}$ & 0.32 & 0.102 & 0.11 \\
\hline Dasytricha spp. & $1.15^{\mathrm{a}}$ & $\mathrm{ND}^{\mathrm{b}}$ & $1.12^{\mathrm{a}}$ & 0.363 & 0.037 \\
\hline Epidinium spp. & 3.20 & ND & 4.80 & 0.745 & 0.067 \\
\hline Ophryoscolex spp. & ND & ND & 0.03 & 0.015 & 0.41 \\
\hline Diplodinium spp. & $1.63^{\mathrm{a}}$ & $\mathrm{ND}^{\mathrm{b}}$ & $2.67^{\mathrm{a}}$ & 0.578 & 0.019 \\
\hline \multicolumn{6}{|l|}{ PSD activities ${ }^{9}$} \\
\hline CMCase & 56 & 108 & 80 & 19.1 & 0.30 \\
\hline Xylanase & 167 & 164 & 185 & 11.9 & 0.52 \\
\hline Amylase & $86^{\mathrm{b}}$ & $133^{\mathrm{a}}$ & $102^{\mathrm{ab}}$ & 9.9 & $0.043^{10}$ \\
\hline \multicolumn{6}{|l|}{ Rumen gases $^{11}$} \\
\hline Nitrous oxide, $\mathrm{mg} / \mathrm{m}^{3}$ & $91^{\mathrm{a}}$ & $70^{\mathrm{b}}$ & $93^{\mathrm{a}}$ & 15.9 & 0.02 \\
\hline Nitrous oxide production rate, $\mathrm{mg} / \mathrm{h}$ & 31 & 26 & 30 & 1.9 & $0.17^{12}$ \\
\hline Methane $\times 10^{3}, \mathrm{mg} / \mathrm{m}^{3}$ & 35.3 & 30.9 & 38.5 & 4.29 & 0.13 \\
\hline Methane production rate, $\mathrm{g} / \mathrm{h}$ & 12.5 & 12.1 & 13.0 & 1.38 & 0.21 \\
\hline Carbon dioxide $\times 10^{3}, \mathrm{mg} / \mathrm{m}^{3}$ & $172^{\mathrm{ab}}$ & $150^{\mathrm{b}}$ & $183^{\mathrm{a}}$ & 18.9 & $0.039^{13}$ \\
\hline Carbon dioxide production rate, $\mathrm{g} / \mathrm{h}$ & 61.9 & 61.7 & 61.9 & 6.78 & 0.98 \\
\hline Methanogen 16S rRNA ${ }^{14}$ & 10.0 & 11.3 & 10.8 & 1.43 & 0.84 \\
\hline \multicolumn{6}{|l|}{ Urinary $\mathrm{PD},{ }^{15} \mathrm{mmol} / \mathrm{d}$} \\
\hline Allantoin & $473^{\mathrm{a}}$ & $328^{\mathrm{b}}$ & $440^{\mathrm{a}}$ & 25.7 & 0.002 \\
\hline Uric acid & $48.5^{\mathrm{a}}$ & $28.5^{\mathrm{b}}$ & $43.9^{\mathrm{a}}$ & 4.75 & 0.008 \\
\hline Total PD & $521^{\mathrm{a}}$ & $356^{\mathrm{b}}$ & $484^{\mathrm{a}}$ & 23.8 & 0.002 \\
\hline $\mathrm{MN},{ }^{16} \mathrm{~g} / \mathrm{d}$ & $348^{\mathrm{a}}$ & $226^{\mathrm{b}}$ & $321^{\mathrm{a}}$ & 16.5 & 0.002 \\
\hline BUN, ${ }^{17} \mathrm{mg} / 100 \mathrm{~mL}$ & 9.5 & 10.1 & 8.6 & 0.53 & 0.20 \\
\hline $0 \mathrm{~h}$ & 9.5 & 8.4 & 8.6 & 0.60 & 0.54 \\
\hline $6 \mathrm{~h}$ & $9.6^{\mathrm{b}}$ & $11.9^{\mathrm{a}}$ & $8.6^{\mathrm{b}}$ & 0.76 & 0.006 \\
\hline Plasma glucose ${ }^{18} \mathrm{mg} / 100 \mathrm{~mL}$ & 60.8 & 60.8 & 59.4 & 2.66 & 0.73 \\
\hline
\end{tabular}

${ }^{\mathrm{a}, \mathrm{b}}$ Within a row, means without a common superscript letter differ $(P<0.05)$.

${ }^{1} \mathrm{SA}=$ stearic acid; $\mathrm{LA}=$ lauric acid; $\mathrm{MA}=$ myristic acid

${ }^{2}$ Treatment $\times$ time interaction, $P=0.69$.

${ }^{3}$ Treatment $\times$ time interaction, $P=0.018$; LA vs. SA, $P=0.084$.

${ }^{4}$ Treatment $\times$ time interactions for VFA, except valerate, $P=0.09$ to 0.69 .

${ }^{5}$ Treatment $\times$ time interaction, $P=0.006$.

${ }^{6}$ LA vs. SA, $P=0.024$.

${ }^{7}$ Actual protozoal counts were $\log _{10}$-transformed for the statistical analysis.

${ }^{8}$ Low counts $=$ below $0.02 \times 10^{4} / \mathrm{mL}$.

${ }^{9} \mathrm{PSD}=$ polysaccharide-degrading activities. Expressed as nanomoles of reducing sugars as glucose released/ $\mathrm{mL}$ of ruminal fluid per minute; CMCase $=$ carboxymethylcellulase.

${ }^{10} \mathrm{LA}$ vs. MA, $P=0.082$.

${ }^{11}$ Average concentration of gases in rumen gas phase across sampling points (see Materials and Methods);

Treatment $\times$ time interactions, $P=0.10$ to 0.61 .

${ }^{12}$ Treatment $\times$ time interactions, $P=0.065$; at $2 \mathrm{~h}$ after feeding. LA vs. MA and SA, $P=0.002$.

${ }^{13}$ LA vs. SA, $P=0.098$.

${ }^{14}$ Methanogen archaea $16 \mathrm{~S}$ rRNA copy, number $\times 10^{4} / \mathrm{ng}$ of total DNA.

${ }^{15}$ Excretion of urinary purine derivatives (PD).

${ }^{16}$ Estimated microbial $\mathrm{N}$ outflow from the rumen (based on urinary allantoin excretion).

${ }^{17}$ Averaged blood plasma urea $\mathrm{N}$, or $0 \mathrm{~h}$ (before a.m. feeding) and $6 \mathrm{~h}$ after the a.m. feeding.

${ }^{18}$ Averaged blood plasma glucose $(0 \mathrm{~h}$ and $6 \mathrm{~h}$ samples did not differ among treatments; $P=0.67$ and 0.85 , respectively). 
Urinary excretion of allantoin and uric acid, and the estimated outflow of microbial protein from the rumen, were reduced $(P=0.002)$ by LA compared with the other treatments. The average concentration of PUN was not different among treatments, but was greater $(P$ $=0.006$ ) for LA compared with SA and MA $6 \mathrm{~h}$ after feeding. Plasma glucose concentration was unaffected by treatment.

Intake of DM was drastically reduced $(P=0.002)$ by LA compared with SA and MA, and similar trends were observed for the other nutrients (Table 3). Totaltract apparent digestibility of dietary nutrients was not affected by treatment. Urinary $\mathrm{N}$ excretion did not differ among treatments, but fecal and total $\mathrm{N}$ excretions were reduced ( $P=0.008$ and $P=0.01$, respectively) by LA compared with SA and MA (Table 4), which was partially due to reduced $\mathrm{N}$ intake but also to proportionally greater (trend of $P=0.111$ ) $\mathrm{N}$ losses in urine with the former treatment.

Milk yield was decreased $(P=0.017)$ by LA compared with the other treatments due to decreased DMI as milk feed efficiency was greater $(P=0.009)$ for LA than SA and MA (Table 5). When expressed on an FCM or milk $\mathrm{NE}_{\mathrm{L}}$ basis, however, LA had no effect on feed efficiency. Milk fat content and yield were decreased $(P=0.021$ and 0.016 , respectively) by LA, which is indicative of milk fat depression. Expressed on a DMI basis, milk fat yield was not statistically different among treatments (although numerically lower for LA). Milk true protein concentration tended to be reduced $(P=0.09)$ by LA compared with SA, and true protein and $\mathrm{N}$ yields were reduced $(P=0.016)$ by LA compared with the other treatments. Milk lactose concentration was not affected by treatment, but lactose yield was reduced $(P=0.018)$ by LA compared with SA and MA. Milk protein and lactose yields per unit of DMI were greater ( $P=0.022$ and 0.024 , respectively) for LA compared with SA. Milk $\mathrm{NE}_{\mathrm{L}}$ output also was lower $(P=0.009)$ for LA, which was due to the lower energy intake with this treatment, but milk $\mathrm{NE}_{\mathrm{L}}$ efficiency was not different among treatments. Lauric acid tended to increase $(P=0.054)$ MUN compared with SA.

Because one group of cows in the Latin square received $\mathrm{rbST}$ and the other did not, the interaction group $\times$ treatment was examined for all variables. The interaction was statistically significant $(P=0.032)$ only for milk fat yield (and the resultant variable, milk fat yield per unit of DMI). Milk fat yield was statistically lower $(P=0.041)$ for LA versus SA cows for the norbST group, but not for the rbST group $(P=0.13)$. As ranking among treatments was similar for both groups, and milk fat yield for LA cows was similarly decreased (60 to $63 \%$ ) compared with SA cows, this interaction was considered to be of no biological significance.

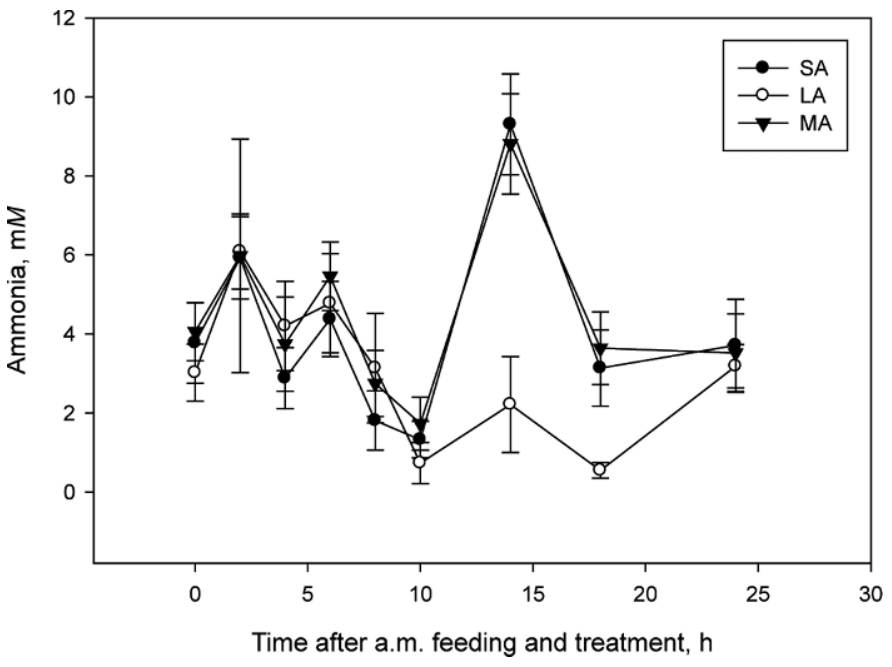

Figure 1. Effect of stearic (SA), lauric (LA), and myristic acids (MA) on ruminal ammonia concentration in dairy cows (means $\pm \mathrm{SE}$; $\mathrm{n}=160)$. Overall treatment effect, $P<0.044$; time of sampling effect, $P<0.001$; treatment $\times$ time interaction, $P=0.018$.

As expected, milk FA concentrations of treatment FA increased due to SA, LA, or MA administration. Milk fat content of 12:0 was more than doubled $(P<$ $0.001)$ by LA and 14:0 was increased $(P<0.001)$ by MA compared with SA (Table 6). Treatment FA also influenced milk FA composition more broadly, and this was especially evident with the LA treatment. In general, concentration of the short-chain FA (4:0 to 10:0) was reduced $(P<0.001)$ by LA and in some cases by MA compared with SA. Myristoleic acid (14:1) also was increased with MA administration. Concentrations of

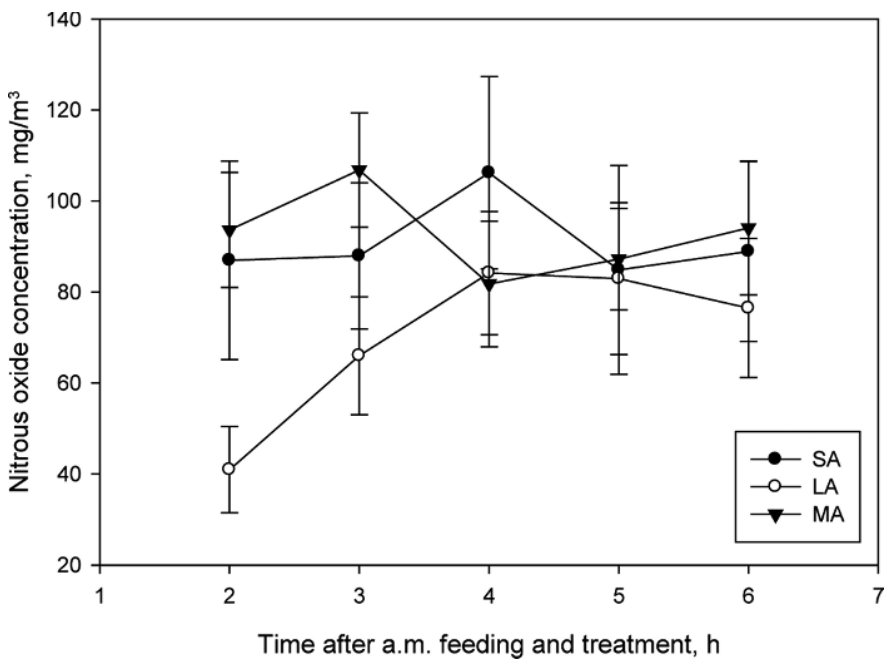

Figure 2. Effect of stearic (SA), lauric (LA), and myristic acids (MA) on nitrous oxide concentration in rumen gas of dairy cows (means $\pm \mathrm{SE} ; \mathrm{n}=90$ ). Overall treatment effect, $P=0.02$; time of sampling effect, $P=0.29$; treatment $\times$ time interaction, $P=0.10$. 
Table 3. Effect of medium-chain saturated fatty acids ${ }^{1}$ on intake and total-tract apparent digestibility of nutrients in dairy cows (least squares means; $\mathrm{n}=18$ )

\begin{tabular}{lccccc}
\hline Item & SA & LA & MA & SEM & $P$-value \\
\hline Intake, kg/d & & & & & \\
DM & $26.9^{\mathrm{a}}$ & $20.0^{\mathrm{b}}$ & $25.7^{\mathrm{a}}$ & 0.84 & 0.002 \\
OM & 25.3 & 18.7 & 24.1 & 0.79 & 0.005 \\
N & $0.627^{\mathrm{a}}$ & $0.463^{\mathrm{b}}$ & $0.592^{\mathrm{a}}$ & 0.0186 & 0.001 \\
NDF & $9.4^{\mathrm{a}}$ & $6.9^{\mathrm{b}}$ & $9.0^{\mathrm{a}}$ & 0.30 & 0.002 \\
ADF & $5.8^{\mathrm{a}}$ & $4.3^{\mathrm{b}}$ & $5.6^{\mathrm{a}}$ & 0.19 & 0.002 \\
Starch & $7.1^{\mathrm{a}}$ & $5.3^{\mathrm{b}}$ & $6.8^{\mathrm{a}}$ & 0.21 & 0.001 \\
Apparent digestibility, & & & & & \\
DM & 65.4 & 67.7 & 67.3 & 2.28 & 0.75 \\
OM & 66.5 & 68.6 & 68.4 & 2.21 & 0.74 \\
N & & & & & \\
NDF & 43.9 & 42.1 & 45.6 & 3.77 & 0.81 \\
ADF & 31.8 & 32.1 & 33.9 & 4.00 & 0.91 \\
Starch & 98.1 & 98.6 & 97.8 & 0.30 & 0.33 \\
\hline
\end{tabular}

${ }^{\mathrm{a}, \mathrm{b}}$ Within a row, means without a common superscript letter differ $(P<0.05)$.

${ }^{1} \mathrm{SA}=$ stearic acid; LA = lauric acid; MA = myristic acid.

major milk FA such as 16:0 and 18:0 were reduced $(P=$ 0.007 and $<0.001$, respectively) by LA compared with the other treatments. Concentrations of trans 18:1 FA (except trans 12) and CLA isomers were increased $(P$ $\leq 0.003$ ) by LA compared with SA and MA. Overall, the concentrations of saturated FA in milk fat were reduced $(P=0.014)$ and that of $>$ C16 FA and MUFA were increased $(P=0.004)$ by LA compared with the other treatments.

The ammonia-emitting potential of manure was greatest $(P<0.001)$ for LA, lowest for SA, and intermediate for MA (Figure 4). The methane-emitting potential of manure was greatest $(P<0.001)$ for MA, lowest for LA, and intermediate for SA (Figure 5). The differences were small, particularly for methane, but highly significant due to the large number of measurements taken during the course of the incubation.

\section{DISCUSSION}

According to NRC (2001), and based on actual forage analyses, the basal diet was deficient in RDP and MP. Our analyses and experimental data (Huhtanen and Hristov, 2009; Lee and Hristov, 2010) and data from this experiment (cows reached their expected production level), however, suggest that NRC (2001) is likely overestimating protein requirements, particularly RDP requirements. Furthermore, inhibition of protozoa in the rumen is more likely to benefit the overall $\mathrm{N}$ efficiency of the cow only in protein deficient situations (Hristov and Jouany, 2005). Therefore, dietary protein level was kept intentionally low in this experiment.

The effect of LA on ruminal fermentation was profound. In agreement with our previous observations (Hristov et al., 2004b, 2009), protozoal counts were reduced by LA to about $4 \%$ of the control (SA) or MA counts. Except for Entodinium spp., no other genera were found in LA-treated cows. By contrast, the other major FA in coconut oil, MA, had no effect on protozoal counts, which is in agreement with our in vitro data (Hristov et al., 2004a) and data from Soliva et al. (2004) in the rumen simulation technique. Matsumoto et al. (1991), however, observed complete defaunation in $3 \mathrm{~d}$ in goats consuming about $5 \%$ (dietary DM basis) MA. At a much higher dose than in the present experiment $(50 \mathrm{~g} / \mathrm{kg}$ of dietary DM, which would correspond to about $1,350 \mathrm{~g} /$ cow in our study), MA significantly reduced protozoal counts in sheep (Machmüller et al., 2003). The effects of LA on ruminal $\mathrm{pH}$, ammonia, and VFA are indicative of effective depression of microbial activities and, for the most part, are similar to our

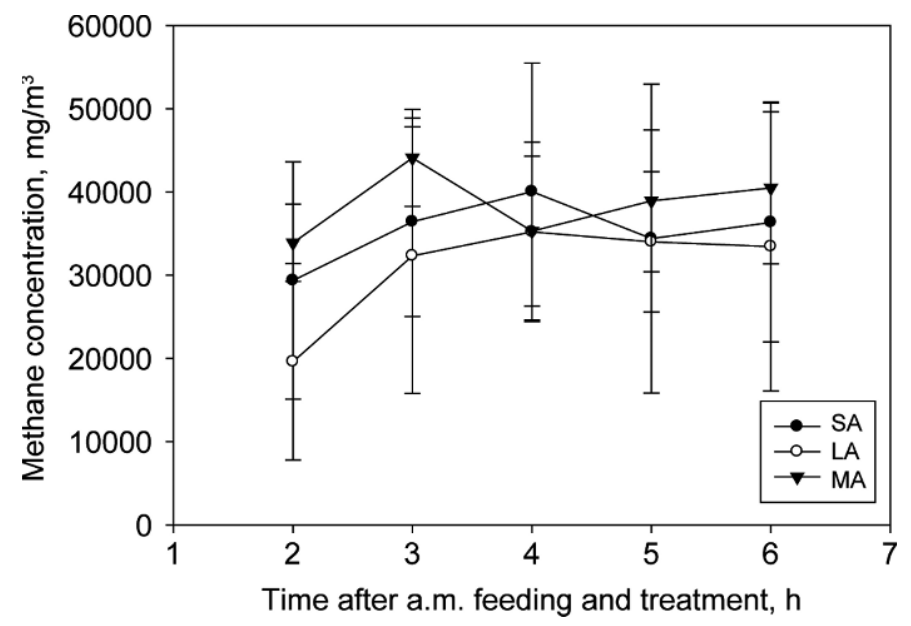

Figure 3. Effect of stearic (SA), lauric (LA), and myristic acids (MA) on methane concentration in rumen gas of dairy cows (means \pm SE; $\mathrm{n}=90)$. Overall treatment effect, $P=0.13$; time of sampling effect, $P=0.013$; treatment $\times$ time interaction, $P=0.61$. 
Table 4. Effect of medium-chain saturated fatty acids ${ }^{1}$ on urinary and fecal $\mathrm{N}$ excretions in dairy cows (least squares means; $\mathrm{n}=18$ )

\begin{tabular}{lccccl}
\hline Item & SA & LA & MA & SEM & $P$-value \\
\hline Urinary N & & & & & \\
g/d & 117 & 113 & 120 & 9.7 & 0.86 \\
As \% of N intake & 19.0 & 24.8 & 20.4 & 2.49 & 0.22 \\
As \% of total excreted N & 32.6 & 43.3 & 35.4 & 3.59 & $0.111^{2}$ \\
Urea N, g/d & 65.8 & 60.5 & 67.2 & 5.48 & 0.60 \\
Fecal N & $241^{\mathrm{a}}$ & $149^{\mathrm{b}}$ & $221^{\mathrm{a}}$ & 14.5 & 0.008 \\
g/d & 39.0 & 32.1 & 37.7 & 2.41 & 0.21 \\
As \% of N intake & & & & & \\
Total N losses & $357^{\mathrm{a}}$ & $262^{\mathrm{b}}$ & $341^{\mathrm{a}}$ & 14.1 & 0.01 \\
g/d A & 58.1 & 56.8 & 58.0 & 2.37 & 0.94 \\
As of N intake & & & &
\end{tabular}

${ }^{\mathrm{a}, \mathrm{b}}$ Within a row, means without a common superscript letter differ $(P<0.05)$.

${ }^{1} \mathrm{SA}=$ stearic acid; $\mathrm{LA}=$ lauric acid; $\mathrm{MA}=$ myristic acid.

${ }^{2}$ LA vs. SA, $P=0.048$.

previous observations (Hristov et al., 2009). One surprising effect of LA was the increased amylase activity of the ruminal contents (compared with SA). Given the apparently inhibited rumen microbial ecosystem with LA, there is no rational explanation for the increased amylase activity, except that amylolytic species may have been proportionally less affected by LA than other generalists and benefited from available substrate.
The decreased microbial production in the rumen with LA is in agreement with the numerically or statistically significant reductions in microbial flow we previously reported for LA and coconut oil (Hristov et al., 2004b, 2009). As in previous studies, the decrease in microbial protein flow with LA is mostly due to decreased DMI. For example, on an OM-intake basis, microbial N flow with LA was approximately $14 \%$ lower than that with

Table 5. Effect of medium-chain saturated fatty acids $^{1}$ on milk yield and composition in dairy cows (least squares means, $\mathrm{n}=18$ )

\begin{tabular}{|c|c|c|c|c|c|}
\hline Item & SA & LA & MA & SEM & $P$-value \\
\hline Milk yield, $\mathrm{kg} / \mathrm{d}$ & $44.6^{\mathrm{a}}$ & $35.8^{\mathrm{b}}$ & $44.2^{\mathrm{a}}$ & 1.70 & 0.017 \\
\hline Milk/DMI & $1.63^{\mathrm{b}}$ & $1.91^{\mathrm{a}}$ & $1.81^{\mathrm{b}}$ & 0.061 & 0.009 \\
\hline Milk fat, $\%$ & $3.42^{\mathrm{a}}$ & $2.59^{\mathrm{b}}$ & $3.12^{\mathrm{ab}}$ & 0.327 & $0.021^{2}$ \\
\hline Yield, kg/d & $1.48^{\mathrm{a}}$ & $0.92^{\mathrm{b}}$ & $1.38^{\mathrm{a}}$ & 0.173 & 0.012 \\
\hline Yield/DMI, g/kg & 54.9 & 48.9 & 56.0 & 6.71 & 0.28 \\
\hline $4 \% \mathrm{FCM}, \mathrm{kg} / \mathrm{d}$ & $39.6^{\mathrm{a}}$ & $28.1^{\mathrm{b}}$ & $38.3^{\mathrm{a}}$ & 3.16 & 0.010 \\
\hline $4 \% \mathrm{FCM} / \mathrm{DMI}$ & 1.48 & 1.50 & 1.56 & 0.121 & 0.56 \\
\hline Milk true protein, $\%$ & 2.98 & 2.90 & 2.89 & 0.032 & $0.09^{3}$ \\
\hline Yield, $\mathrm{kg} / \mathrm{d}$ & $1.30^{\mathrm{a}}$ & $1.04^{\mathrm{b}}$ & $1.27^{\mathrm{a}}$ & 0.055 & 0.016 \\
\hline Yield/DMI, g/kg & $48.4^{\mathrm{b}}$ & $55.2^{\mathrm{a}}$ & $51.8^{\mathrm{ab}}$ & 1.90 & 0.022 \\
\hline $\mathrm{N}$ yield,${ }^{4} \mathrm{~g} / \mathrm{d}$ & $204^{\mathrm{a}}$ & $162^{\mathrm{b}}$ & $200^{\mathrm{a}}$ & 8.7 & 0.016 \\
\hline As $\%$ of $\mathrm{N}$ intake & 32.6 & 34.9 & 33.9 & 1.08 & 0.24 \\
\hline Milk lactose, $\%$ & 4.84 & 4.78 & 4.78 & 0.135 & 0.18 \\
\hline Yield, kg/d & $2.11^{\mathrm{a}}$ & $1.71^{\mathrm{b}}$ & $2.11^{\mathrm{a}}$ & 0.119 & 0.018 \\
\hline Yield/DMI, g/kg & $78.9^{\mathrm{b}}$ & $91.6^{\mathrm{a}}$ & $86.2^{\mathrm{ab}}$ & 5.00 & 0.024 \\
\hline Milk $\mathrm{NE}_{\mathrm{L}},{ }^{5} \mathrm{Mcal} / \mathrm{d}$ & $29.4^{\mathrm{a}}$ & $21.1^{\mathrm{b}}$ & $28.3^{\mathrm{a}}$ & 2.31 & 0.009 \\
\hline Milk NE $/$ DMI, Mcal/kg & 1.09 & 1.13 & 1.15 & 0.090 & 0.58 \\
\hline $\mathrm{NE}_{\mathrm{L}}$ intake, ${ }^{6} \mathrm{Mcal} / \mathrm{d}$ & $46.1^{\mathrm{a}}$ & $34.4^{\mathrm{b}}$ & $44.0^{\mathrm{a}}$ & 1.40 & 0.002 \\
\hline Milk $\mathrm{NE}_{\mathrm{L}}$ as $\%$ of $\mathrm{NE}_{\mathrm{L}}$ intake & 63.5 & 60.7 & 64.9 & 4.91 & 0.56 \\
\hline MUN, mg/100 mL & 7.7 & 9.7 & 8.3 & 0.52 & $0.054^{7}$ \\
\hline $\mathrm{BW}, \mathrm{kg}$ & 672 & 665 & 661 & 45.2 & 0.36 \\
\hline
\end{tabular}

${ }^{a, b}$ Within a row, means without a common superscript letter differ $(P<0.05)$.

${ }^{1} \mathrm{SA}=$ stearic acid; LA = lauric acid; $\mathrm{MA}=$ myristic acid.

${ }^{2}$ LA vs. MA, $P=0.053$.

${ }^{3}$ LA vs. SA, $P=0.061 ;$ MA vs. SA, $P=0.050$.

${ }^{4}$ Milk true protein yield $\div 6.38$.

${ }^{5} \mathrm{Milk} \mathrm{NE}_{\mathrm{L}}(\mathrm{Mcal} / \mathrm{d})=\mathrm{kg}$ of milk $\times(0.0929 \times \%$ fat $+0.0563 \times \%$ true protein $+0.0395 \times \%$ lactose $)(\mathrm{NRC}$, 2001).

${ }^{6}$ Based on $\mathrm{NE}_{\mathrm{L}}$ concentration of the basal diet (Table 1), DMI (Table 3), and calculated $\mathrm{NE}_{\mathrm{L}}$ intake with SA, LA, and MA (NRC, 2001, at actual DMI).

${ }^{7}$ LA vs. SA, $P=0.021 ;$ LA vs. MA, $P=0.082$. 


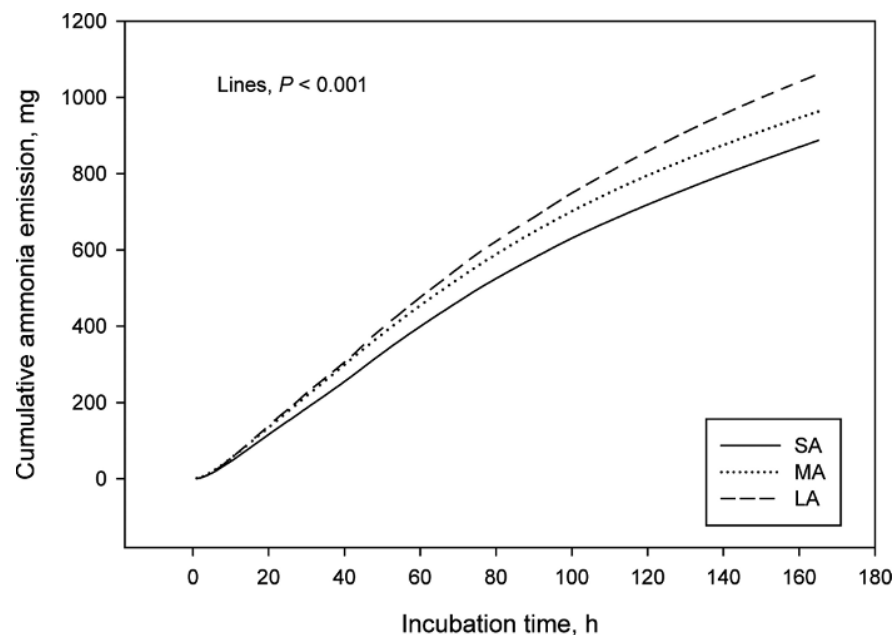

Figure 4. Effect of stearic (SA), lauric (LA), and myristic acids (MA) on cumulative ammonia emission from dairy manure. End-point $(165 \mathrm{~h})$ cumulative ammonia emission $(\mathrm{n}=18 ; P=0.073): 887,1,061$, and $962 \mathrm{mg}$ (SA, LA, and MA, respectively). Comparison of regression lines $(\mathrm{n}=3,366), P<0.001$.
SA (12.1 vs. $13.8 \mathrm{~g} / \mathrm{kg}$ of OM, respectively). Numerical trends for depressed DMI with LA (or coconut oil) was also observed in our previous experiments (Hristov et al., 2004b, 2009) and was reported by others (Faciola et al., 2005, 2008; Hollmann and Beede, 2008), but the effect was more pronounced in this experiment. Similar to our previous studies (Hristov et al., 2004b, 2009), total-tract nutrient digestibility did not seem to be affected by LA (or MA). Others have not found a depression in digestibility of DM, OM, or fiber fractions with LA, MA, or coconut oil (Machmüller et al., 2003; Dohme et al., 2004; Jordan et al., 2006). Thus, it appears that palatability and reduced DMI are the major factors leading to decreased microbial protein synthesis with MCSFA or coconut oil, which perhaps counteracts the beneficial effect of inhibited protozoal population on microbial protein production in the rumen (Hristov and Jouany, 2005). The reduced DMI with LA was responsible for the reduced milk yield in this experiment. Cows treated with LA more efficiently utilized

Table 6. Effect of medium-chain saturated fatty acids ${ }^{1}$ on milk fatty acid composition (g/100 $\mathrm{g}$ of total fatty acids) in dairy cows (least squares means; $\mathrm{n}=18$ )

\begin{tabular}{|c|c|c|c|c|c|}
\hline Fatty acid & $\mathrm{SA}$ & LA & MA & SEM & $P$-value \\
\hline $4: 0$ & $5.03^{\mathrm{a}}$ & $3.64^{\mathrm{b}}$ & $4.75^{\mathrm{a}}$ & 0.321 & $<0.001$ \\
\hline $6: 0$ & $2.48^{\mathrm{a}}$ & $1.49^{\mathrm{c}}$ & $2.23^{\mathrm{b}}$ & 0.208 & $<0.001$ \\
\hline $8: 0$ & $1.33^{\mathrm{a}}$ & $0.75^{\mathrm{c}}$ & $1.17^{\mathrm{b}}$ & 0.124 & $<0.001$ \\
\hline 10:0 & $2.79^{\mathrm{a}}$ & $1.64^{\mathrm{b}}$ & $2.46^{\mathrm{a}}$ & 0.264 & $<0.001$ \\
\hline $12: 0$ & $2.93^{\mathrm{b}}$ & $6.27^{\mathrm{a}}$ & $2.67^{\mathrm{b}}$ & 0.263 & $<0.001$ \\
\hline $14: 0$ & $9.45^{\mathrm{b}}$ & $7.66^{\mathrm{c}}$ & $13.58^{\mathrm{a}}$ & 0.349 & $<0.001$ \\
\hline $14: 1$ & $0.71^{\mathrm{b}}$ & $0.86^{\mathrm{a}}$ & $1.08^{\mathrm{a}}$ & 0.135 & 0.007 \\
\hline $15: 0$ & 0.69 & 0.65 & 0.68 & 0.040 & 0.73 \\
\hline $16: 0$ & $22.6^{\mathrm{a}}$ & $20.1^{\mathrm{b}}$ & $22.3^{\mathrm{a}}$ & 0.42 & 0.007 \\
\hline $16: 1$ & $1.07^{\mathrm{b}}$ & $1.60^{\mathrm{a}}$ & $1.44^{\mathrm{b}}$ & 0.188 & $<0.001$ \\
\hline $17: 0$ & 0.36 & 0.36 & 0.33 & 0.023 & 0.18 \\
\hline $18: 0$ & $13.2^{\mathrm{a}}$ & $9.7^{\mathrm{c}}$ & $11.7^{\mathrm{b}}$ & 1.11 & $<0.001$ \\
\hline $18: 1$ trans $-6-8$ & $0.56^{\mathrm{b}}$ & $1.31^{\mathrm{a}}$ & $0.57^{\mathrm{b}}$ & 0.121 & 0.003 \\
\hline $18: 1$ trans -9 & $0.39^{\mathrm{b}}$ & $0.80^{\mathrm{a}}$ & $0.40^{\mathrm{b}}$ & 0.061 & 0.002 \\
\hline 18:1 trans -10 & $0.74^{\mathrm{b}}$ & $5.29^{\mathrm{a}}$ & $1.20^{\mathrm{b}}$ & 0.558 & 0.001 \\
\hline 18:1 trans -11 & $1.67^{\mathrm{b}}$ & $2.60^{\mathrm{a}}$ & $1.69^{\mathrm{b}}$ & 0.119 & 0.003 \\
\hline 18:1 trans -12 & 0.68 & 0.75 & 0.67 & 0.034 & 0.27 \\
\hline $18: 1$ cis-9 & 25.0 & 25.4 & 23.4 & 1.08 & 0.47 \\
\hline $18: 2$ cis- 9, cis- 12 & 4.35 & 4.23 & 4.08 & 0.164 & 0.41 \\
\hline $\mathrm{CLA}^{2}$ cis-9, trans-11 & $0.62^{\mathrm{b}}$ & $1.13^{\mathrm{a}}$ & $0.66^{\mathrm{b}}$ & 0.139 & $<0.001$ \\
\hline CLA trans-10, cis-12 & $\mathrm{ND}^{3 \mathrm{~b}}$ & $0.02^{\mathrm{a}}$ & $0.004^{\mathrm{b}}$ & 0.003 & 0.001 \\
\hline $18: 3$ & $0.43^{\mathrm{a}}$ & $0.38^{\mathrm{b}}$ & $0.39^{\mathrm{b}}$ & 0.009 & 0.038 \\
\hline $20: 0$ & $0.15^{\mathrm{a}}$ & $0.12^{\mathrm{b}}$ & $0.14^{\mathrm{ab}}$ & 0.008 & 0.022 \\
\hline$\Sigma$ unidentified & $2.71^{\mathrm{b}}$ & $3.20^{\mathrm{a}}$ & $2.63^{\mathrm{b}}$ & 0.138 & $<0.001$ \\
\hline$\Sigma$ trans-18:1 & $4.04^{\mathrm{b}}$ & $10.7^{\mathrm{a}}$ & $4.52^{\mathrm{b}}$ & 0.709 & $<0.001$ \\
\hline$\Sigma<\mathrm{C} 16$ & $25.4^{\mathrm{b}}$ & $23.0^{\mathrm{b}}$ & $28.6^{\mathrm{a}}$ & 1.01 & 0.011 \\
\hline$\Sigma \mathrm{C} 16$ & $23.6^{\mathrm{a}}$ & $21.7^{\mathrm{b}}$ & $23.5^{\mathrm{a}}$ & 0.54 & 0.027 \\
\hline$\Sigma>\mathrm{C} 16$ & $50.9^{\mathrm{b}}$ & $55.3^{\mathrm{a}}$ & $47.9^{\mathrm{b}}$ & 1.12 & 0.014 \\
\hline$\Sigma$ saturated fatty acids & $61.0^{\mathrm{a}}$ & $52.4^{\mathrm{b}}$ & $62.0^{\mathrm{a}}$ & 2.01 & 0.003 \\
\hline$\Sigma \mathrm{MUFA}^{4}$ & $30.9^{\mathrm{b}}$ & $38.6^{\mathrm{a}}$ & $30.2^{\mathrm{b}}$ & 1.65 & 0.004 \\
\hline$\Sigma \mathrm{PUFA}^{4}$ & $5.39^{\mathrm{ab}}$ & $5.76^{\mathrm{a}}$ & $5.14^{\mathrm{b}}$ & 0.289 & $0.038^{5}$ \\
\hline
\end{tabular}

${ }^{a-c}$ Within a row, means without a common superscript letter differ $(P<0.05)$.

${ }^{1} \mathrm{SA}=$ stearic acid; $\mathrm{LA}=$ lauric acid; $\mathrm{MA}=$ myristic acid.

${ }^{2} \mathrm{CLA}=$ conjugated linoleic acid.

${ }^{3} \mathrm{ND}=$ not detected

${ }^{4}$ MUFA, monounsaturated fatty acids; PUFA, polyunsaturated fatty acids.

${ }^{5}$ LA vs. SA, $P=0.103$. 


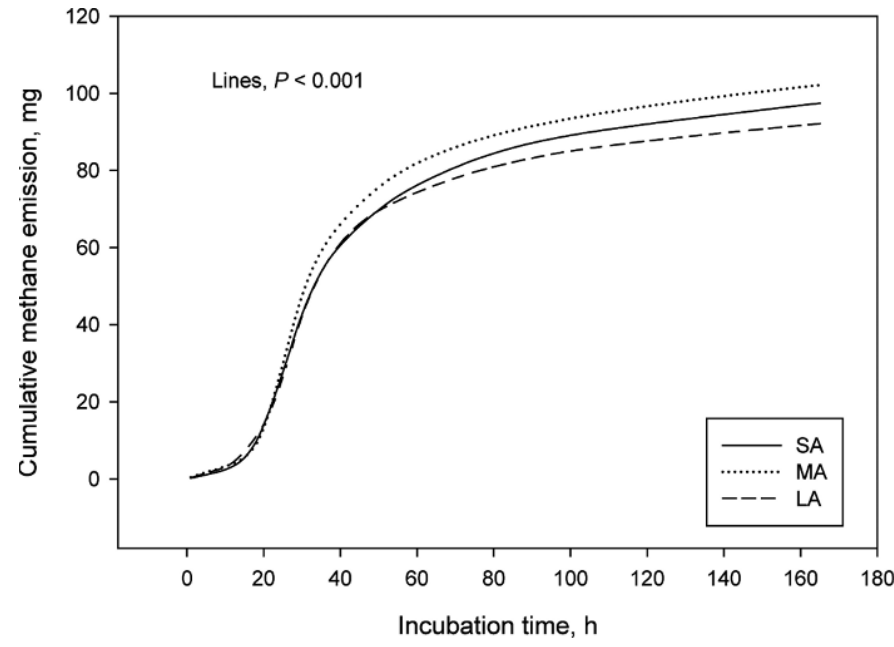

Figure 5. Effect of stearic (SA), lauric (LA), and myristic acids (MA) on cumulative methane emission from dairy manure. End-point $(165 \mathrm{~h})$ cumulative methane emission $(\mathrm{n}=18 ; P=0.49): 97,92$, and $102 \mathrm{mg}$ (SA, LA, and MA, respectively). Comparison of regression lines $(\mathrm{n}=3,366), P<0.001$.

dietary nutrients for milk protein and lactose synthesis than cows on SA. Similar trends for increased milk feed efficiency with LA or coconut oil were observed by Faciola et al. (2008; 1.37 vs. $1.55 \mathrm{~kg} / \mathrm{kg}$, control and highest levels of LA) and Hollmann and Beede (2008; 1.58 vs. $1.62 \mathrm{~kg} / \mathrm{kg}$ for control and $2.5 \%$ coconut oil, respectively). Due to the milk fat depression effect of LA, however, when expressed on an FCM or milk $\mathrm{NE}_{\mathrm{L}}$ basis, feed efficiency was not different between LA and the other treatments.

Lauric and myristic acids had no effect on ruminal methane production in this experiment. Methane production was reduced with MA (50 g/ $\mathrm{kg}$ of dietary DM) in the experiment by Machmüller et al. (2003). Such high application levels, however, cannot be considered a practical approach for reducing methane emissions from ruminants. The lack of effect of LA (or MA) on methane production in this experiment is difficult to explain. The intention of the study was to identify which of the $2 \mathrm{FA}$ is responsible for the methane-suppressing effect of coconut oil (Hristov et al., 2009). Similar to our observations, in beef cattle fed about $48 \%$ forage diet, coconut oil supplemented at $250 \mathrm{~g} / \mathrm{d}$ suppressed methane production by about $20 \%$, an effect accompanied by a $63 \%$ reduction in protozoal counts (Jordan et al., 2006). A similar antiprotozoal and methane-mitigating effect was observed for the other source of LA and MA in this study, copra meal. The effect of LA and MA on rumen methanogenesis, however, has been inconsistent [the reader is referred to Hristov et al. (2009) for an extended discussion on the topic]. It was expected that LA would exert a methane-inhibitory effect through its strong antiprotozoal activities. This, however, was not the case in Hristov et al. (2009) or in this study. This is the first study in which we evaluated the rumen effects of MA, and its methane-suppressing effect is apparently nonexistent (at the application level studied). It must be pointed out that the application level of coconut oil in Hristov et al. (2009) was considerably higher than for any of the FA in this experiment. Therefore, we conclude that the antimethanogenic effect of coconut oil reported by Hristov et al. (2009) is likely due to (1) greater application level of total MCSFA and (2) a possible additive effect of LA and MA, as neither of these FA exhibits antimethanogenic effects individually. Another puzzling observation in this and the Hristov et al. (2009) reports is that, despite the dramatic decrease in protozoal counts, methanogen-specific DGGE did not reveal any treatment-specific banding patterns. This is in apparent contrast with reports that protozoalassociated methanogens account for up to $90 \%$ of the ruminal methanogen population in the rumen (Sharp et al., 1998). Again, a detailed discussion on this discrepancy was provided in Hristov et al. (2009), but it is likely that hydrogen concentration, a measure missing in this experiment, rather than methanogen populations, might be a key factor regulating methane production in the rumen. These data also question the applicability of the DGGE technique for quantitative analyses of methanogenic populations in ruminal contents in vivo.

Ruminal concentration of nitrous oxide, a potent GHG, was very low in this experiment, similar to our previous observations (Hristov et al., 2010), but was reduced by LA, which corresponded to the reduced ammonia concentration with that treatment and may be indicative of ammonium oxidation processes (Yoshida and Alexander, 1970). The global-warming potential of nitrous oxide for the 100-yr time horizon is 298 times that of carbon dioxide, or about 10 times the global warming potential of methane (Forster et al., 2007). Thus, on a carbon dioxide-equivalent basis, nitrous oxide emissions from the rumen in this study would be about 2 to $3 \%$ of that of methane.

Milk FA composition reflected the administration of treatment FA with increases in concentration of SA, LA, or MA. The implications of such a significant increase in milk MCSFA to human health have been discussed in detail (Hristov et al., 2009). Stearic acid was chosen as control in this experiment because of its minimal effects on ruminal fermentation (Noble et al., 1969; Hristov et al., 2004a). Stearic acid, however, included at 5 or $10 \%$ in the concentrate mixture had profound effects on milk FA composition; C18:0 and 18:1 were increased and concentrations of shorter chain FA (from C6:0 to C10:0, but also C14:0, 14:0, 14:1, and 16:0), as well as C18:2, were decreased (Noble et al., 1969). The 
MA treatment increased 14:1 in addition to 14:0, and this presumably resulted from mammary stearoyl-CoA desaturase activity. An analogous increase in 18:1, cis-9 was not observed with SA despite increases in milk fat 18:0. Profound changes in the concentration and profile of milk fat trans-18:1 and CLA isomers were observed with LA. These changes tend to be associated with milk fat depression and this treatment did reduce milk lipogenesis, reducing milk fat concentration by about $25 \%$ compared with SA. As pointed out by Shingfield and Griinari (2007), CLA isomers such as trans-10, cis-12 had been implicated in milk fat depression. In this study, however, trans-10, cis-12 concentration was negligible (although increased significantly by LA). Concentration of cis-9, trans-11, on the other hand, was almost doubled by LA, reaching $1.1 \%$ of total milk fat, and may indicate production of other CLA isomers not measured or detected that could result in milk fat depression (Shingfield and Griinari, 2007). No statistically significant changes in CLA isomers were observed for MA, which produced only a numerical decrease in milk fat. Other changes in milk FA composition, including reductions in shorter-chain FA also are characteristic of this situation. Alterations in trans-18:1 and CLA isomers indicate that LA influenced ruminal biohydrogenation and, based on reductions in 18:0, resulted in diminished reduction of biohydrogenation intermediates to the terminal product of biohydrogenation, 18:0. The dramatic increase in trans-18:1 by LA compared with both SA and MA is in agreement with diet-induced milk fat depression (Shingfield and Griinari, 2007). The discrepancy between the influence of LA on ruminal microbes in comparison to MA is unresolved.

\section{CONCLUSIONS}

Lauric acid had a dramatic effect on ruminal fermentation in this study. Protozoal counts were reduced by $96 \%$ and the effects on VFA concentrations and estimated microbial protein production were indicative of general suppression of microbial activities. No such effects were observed for myristic acid. Both lauric and myristic acids had no effect on ruminal methane production, which, for lauric acid, is in contrast to the observed significant reduction of protozoal counts. This and the lack of effect of treatment (specifically lauric acid) on methanogen-specific DGGE banding patterns may be indicative of other factors, such as hydrogen accumulation, important in regulating methane production in the rumen. Lauric acid depressed DMI and consequently milk yield, and also caused milk fat depression. All treatments increased milk concentration of the respective fatty acid. Concentrations of saturated fatty acids in milk were reduced and that of $>\mathrm{C} 16$ and MUFA were increased by lauric acid. Lauric acid increased concentrations of trans-18:1 FA and CLA isomers, which was the likely causative factor for the observed milk fat depression with this treatment.

\section{ACKNOWLEDGMENTS}

This study was supported by funds from the Department of Dairy and Animal Science and the College of Agricultural Science, The Pennsylvania State University (University Park). The authors thank K. Johnson (Department of Animal Science, Washington State University) for providing the $\mathrm{SF}_{6}$ permeation tubes, P. Topper (Department of Agricultural and Biological Engineering, The Pennsylvania State University) for analyzing gaseous emission potential of manure, W. Price (Statistical Programs, College of Agricultural and Life Sciences, University of Idaho) for assistance with statistical evaluation of the results, and the staff of the Department of Dairy and Animal Science Dairy Center for their conscientious care of the experimental cows.

\section{REFERENCES}

AOAC. 1980. Official Methods of Analysis. 13th ed. AOAC, Arlington, VA.

AOAC. 2000. Official Methods of Analysis. 17th ed. AOAC, Arlington, VA.

Bates, D. M., and D. G. Watts. 1988. Nonlinear Regression Analysis and Its Applications. John Wiley \& Sons, New York, NY.

Beauchemin, K. A., S. M. McGinn, C. Benchaar, and L. Holtshausen. 2009. Crushed sunflower, flax, or canola seeds in lactating dairy cow diets: Effects on methane production, rumen fermentation, and milk production. J. Dairy Sci. 92:2118-2127.

Boadi, D., C. Benchaar, J. Chiquette, and D. Massé. 2004. Mitigation strategies to reduce enteric methane emissions from dairy cows: Update review. Can. J. Anim. Sci. 84:319-335.

Bodas, R., S. Lopez, M. Fernandez, R. Garcia-Gonzalez, A. B. Rodriguez, R. J. Wallace, and J. S. Gonzalez. 2008. In vitro screening of the potential of numerous plant species as antimethanogenic feed additives for ruminants. Anim. Feed Sci. Technol. 145:245-258.

Chaney, A. L., and E. P. Marbach. 1962. Modified reagents for determination of urea and ammonia. Clin. Chem. 8:130-132.

Chen, X. B. 1989. Excretion of purine derivatives by sheep and cattle and its use for estimation of absorbed microbial protein. $\mathrm{PhD}$ Thesis. University of Aberdeen, UK.

CRC. 1988. CRC Handbook of Chemistry and Physics. 69th ed. R. C. Weast, M. J. Astle, and W. H. Beyer, ed. CRC Press Inc., Boca Raton, FL

Dehority, B. A. 1993. Laboratory Manual for Classification and Morphology of Rumen Ciliate Protozoa. CRC Press, Inc., Boca Raton, FL.

Dohme, F., A. Machmüller, B. L. Estermann, P. Pfister, A. Wasserfallen, and M. Kreuzer. 1999. The role of the rumen ciliate protozoa for methane suppression caused by coconut oil. Lett. Appl. Microbiol. 29:187-192.

Dohme, F., A. Machmüller, F. Sutter, and M. Kreuzer. 2004. Digestive and metabolic utilization of lauric, myristic and stearic acid in cows, and associated effects on milk fat quality. Arch. Anim. Nutr. 58:99-116.

Dohme, F., A. Machmüller, A. Wasserfallen, and M. Kreuzer. 2001. Ruminal methanogenesis as influenced by individual fattyacids supplemented to complete ruminant diets. Lett. Appl. Microbiol. $32: 47-51$. 
Faciola, A. P., G. A. Broderick, A. N. Hristov, and M. I. Leão. 2005. Effect of feeding different levels of lauric acid on ruminal protozoa, and milk production in dairy cows. J. Dairy Sci. 88(Suppl. 1):178. (Abstr.)

Faciola, A. P., G. A. Broderick, A. N. Hristov, and J. A. Pires. 2008. Effect of four levels of lauric acid on ruminal protozoa, milk production and composition in dairy cows. J. Dairy Sci. 91(Suppl. 1):76. (Abstr.)

FAOUN. 2006. Livestock's long shadow: Environmental issues and options. Accessed October 24, 2010. http://www.fao.org/docrep/010/ a0701e/a0701e00.htm.

Foley, A. E., A. N. Hristov, A. Melgar, J. K. Ropp, R. P. Etter, S. Zaman, C. W. Hunt, K. Huber, and W. J. Price. 2006. Effect of barley and its amylopectin content on ruminal fermentation and nitrogen utilization in lactating dairy cows. J. Dairy Sci. 89:4321-4335.

Forster, P., V. Ramaswamy, P. Artaxo, T. Berntsen, R. Betts, D. W. Fahey, J. Haywood, J. Lean, D. C. Lowe, G. Myhre, J. Nganga, R. Prinn, G. Raga, M. Schulz, and R. Van Dorland. 2007. Changes in atmospheric constituents and in radiative forcing. Pages 129-234 in Climate Change 2007: The Physical Science Basis. Contribution of Working Group I to the Fourth Assessment Report of the Intergovernmental Panel on Climate Change. S. Solomon, D. Qin, M. Manning, Z. Chen, M. Marquis, K. B. Averyt, M. Tignor, and H. L. Miller, ed. Cambridge University Press, Cambridge, UK.

Henderson, C. 1973. The effects of fatty acids on pure cultures of rumen bacteria. J. Agric. Sci. 81:107-112.

Hollmann, M., and D. K. Beede. 2008. Dietary coconut oil and animal fat blend decrease lactational performance of Holstein cows fed a high starch diet. J. Dairy Sci. 91(Suppl. 1):331.

Hristov, A. N. 2008. Livestock's contribution to U.S. greenhouse gas emissions. Hoard's Dairyman Oct. 10:622.

Hristov, A. N., K. L. Grandeen, J. K. Ropp, and M. A. McGuire. 2004b. Effect of sodium laurate on ruminal fermentation and utilization of ruminal ammonia nitrogen for milk protein synthesis in dairy cows. J. Dairy Sci. 87:1820-1831.

Hristov, A. N., M. Ivan, and T. A. McAllister. 2004a. In vitro effects of individual fatty acids on protozoal numbers and on fermentation products in ruminal fluid from cattle fed a high concentrate, barley-based diet. J. Anim. Sci. 82:2693-2704.

Hristov, A. N., M. Ivan, L. M. Rode, and T. A. McAllister. 2001 Fermentation characteristics and ruminal ciliate protozoal populations in cattle fed medium- or high-concentrate barley-based diets. J. Anim. Sci. 79:515-524.

Hristov, A. N., and J.-P. Jouany. 2005. Factors affecting the efficiency of nitrogen utilization in the rumen. Pages 117-166 in Nitrogen and Phosphorus Nutrition of Cattle and Environment. A. N. Hristov and E. Pfeffer, ed. CAB International, Wallingford, UK.

Hristov, A. N., T. A. McAllister, and K.-J. Cheng. 1998. Effect of dietary or abomasal supplementation of exogenous polysaccharidedegrading enzymes on rumen fermentation and nutrient digestibility. J. Anim. Sci. 76:3146-3156.

Hristov, A. N., M. Vander Pol, M. Agle, S. Zaman, C. Schneider, P. Ndegwa, V. K. Vaddella, K. Johnson, K. J. Shingfield, and S. K. R. Karnati. 2009. Effect of lauric acid and coconut oil on ruminal fermentation, digestion, ammonia losses from manure, and milk fatty acid composition in lactating cows. J. Dairy Sci. 92:55615582.

Hristov, A. N., G. Varga, T. Cassidy, M. Long, K. Heyler, K. R. Karnati, B. Corl, C. J. Hovde, and I. Yoon. 2010. Effect of yeast culture on ruminal fermentation and nutrient utilization in dairy cows. J. Dairy Sci. 93:682-692.

Huhtanen, P., and A. N. Hristov. 2009. A meta-analysis of the effects of protein concentration and degradability on milk protein yield and milk $\mathrm{n}$ efficiency in dairy cows. J. Dairy Sci. 92:3222-3232.

Johnson, K. A., M. T. Huyler, H. H. Westberg, B. K. Lamb, and P. Zimmerman. 1994. Measurement of methane emissions from ruminant livestock using a $\mathrm{SF}_{6}$ tracer technique. Environ. Sci. Technol. $28: 359-362$.

Johnson, M. C., A. A. Devine, J. C. Ellis, A. M. Grunden, and V. Fellner. 2009. Effects of antibiotics and oil on microbial profiles and fermentation in mixed cultures of ruminal microorganisms. J. Dairy Sci. 92:4467-4480.

Jordan, E., D. K. Lovett, F. J. Monahan, J. Callan, B. Flynn, and F. P. O'Mara. 2006. Effect of refined coconut oil or copra meal on methane output and on intake and performance of beef heifers. J. Anim. Sci. 84:162-170.

Karnati, S. K. R., Z. Yu, and J. L. Firkins. 2009. Investigating unsaturated fat, monensin, or bromoethanesulfonate in continuous cultures retaining ruminal protozoa. II. Interaction of treatment and presence of protozoa on prokaryotic communities. J. Dairy Sci. 92:3861-3873

Lee, C., and A. N. Hristov. 2010. Effects of dietary protein concentration and coconut oil supplementation on nitrogen utilization in dairy cows. J. Dairy Sci. 92. In press.

Machmüller, A., and M. Kreuzer. 1999. Methane suppression by coconut oil and associated effects on nutrient and energy balance in sheep. Can. J. Anim. Sci. 79:65-72.

Machmüller, A. 2006. Medium-chain fatty acids and their potential to reduce methanogenesis in domestic ruminants. Agric. Ecosyst. Environ. 112:107-114.

Machmüller, A., C. R. Soliva, and M. Kreuzer. 2003. Methane-suppressing effect of myristic acid in sheep as affected by dietary calcium and forage proportion. Br. J. Nutr. 90:529-540.

Matsumoto, M., T. Kobayashi, A. Takenaka, and H. Itabashi. 1991 Defaunation effects of medium-chain fatty acids and their derivatives on goat rumen protozoa. J. Gen. Appl. Microbiol. 37:439445.

McCleary, B. V., V. Solah, and T. S. Gibson. 1994. Quantitative measurement of total starch in cereal flours and products. J. Cereal Sci. 20:51-58.

Moe, P. W., and H. F. Tyrrell. 1979. Methane production in dairy cows. J. Dairy Sci. 62:1583-1586.

Muyzer, G., and K. Smalla. 1998. Application of denaturing gradient gel electrophoresis (DGGE) and temperature gradient gel electrophoresis (TGGE) in microbial ecology. Antonie van Leeuwenhoek $73: 127-141$

Noble, R. C., W. Steele, and J. H. Moore. 1969. The effects of dietary palmitic and stearic acids on milk fat composition in the cow. J. Dairy Res. 36:375-381.

NRC. 2001. Nutrient Requirements of Dairy Cattle. 7th rev. ed. National Academy Press, Washington, DC.

Odongo, N. E., M. M. Or-Rashid, E. Kebreab, J. France, and B. W McBride. 2007. Effect of supplementing myristic acid in dairy cow rations on ruminal methanogenesis and fatty acid profile in milk. J. Dairy Sci. 90:1851-1858.

Ohene-Adjei, S., R. M. Teather, M. Ivan, and R. J. Forster. 2007. Postinoculation protozoan establishment and association patterns of methanogenic archaea in the ovine rumen. Appl. Environ. Microbiol. 73:4609-4618.

Pitesky, M. E., K. R. Stackhouse, and F. M. Mitloehner. 2009. Clearing the air: livestock's contribution to climate change. Adv. Agron. 103:1-40.

Sharp, R., C. J. Ziemer, M. D. Stern, and D. A. Stahl. 1998. Taxon specific association between protozoal and methanogen populations in the rumen and a model rumen system. FEMS Microbiol. Ecol. 26:71-78.

Shingfield, K. J., and J. M. Griinari. 2007. Role of biohydrogenation intermediates in milk fat depression. Eur. J. Lipid Sci. Technol. 109:799-816.

Snell, F. D., and C. T. Snell. 1954. Amino acids. Pages 104-169 in Colorimetric Methods of Analysis. Vol. 4. F. D. Snell and C. T. Snell, ed. D. Van Nostrand Co. Inc., Princeton, NJ.

Soliva, C. R., I. K. Hindrichsen, L. Meile, M. Kreuzer, and A. Machmüller. 2003. Effects of mixtures of lauric and myristic acid on rumen methanogens and methanogenesis in vitro. Lett. Appl. Microbiol. 37:35-39.

Soliva, C. R., L. Meile, A. Cieślak, M. Kreuzer, and A. Machmüller. 2004. Rumen simulation technique study on the interactions of dietary lauric and myristic acid supplementation in suppressing ruminal methanogenesis. Br. J. Nutr. 92:689-700. 
US EPA. 2007. Inventory of U.S. Greenhouse Gas Emissions and Sinks: 1990-2005. Washington, DC.

Valadares, R. F. D., G. A. Broderick, S. C. Valadares Filho, and M. K. Clayton. 1999. Effect of replacing alfalfa silage with high moisture corn on ruminal protein synthesis estimated from excretion of total purine derivatives. J. Dairy Sci. 82:2686-2696.

Van Keulen, J., and B. A. Young. 1977. Evaluation of acid-insoluble ash as a natural marker in ruminant digestibility studies. J. Anim. Sci. 44:282-287.

Van Soest, P. J., J. B. Robertson, and B. A. Lewis. 1991. Methods for dietary fiber, neutral detergent fiber, and nonstarch polysaccharides in relation to animal nutrition. J. Dairy Sci. 74:3583-3597.
Wheeler, E. F., P. A. Topper, N. E. Brown, and G. A. Varga. 2007. Multiple-chamber steady-state gas emission detection from dairy manure slurry. Proc. Int. Symp. Air Quality and Waste Management for Agriculture, Broomfield, CO. ASABE Publication No. 701P0907cd. ASABE, St. Joseph, MI.

Yang, C.-M. Jr., and G. A. Varga. 1989. Effect of three concentrate feeding frequencies on rumen protozoa, rumen digesta kinetics, and milk yield in dairy cows. J. Dairy Sci. 72:950-957.

Yoshida, T., and M. Alexander. 1970. Nitrous oxide formation by $\mathrm{Ni}$ trosomonas europaea and heterotrophie microorganisms. Soil Sci. Soc. Am. J. 34:880-882. 